\title{
Sistem Informasi Manajemen Sebagai Alat Pengelolaan Penelitian Dosen
}

\author{
I Dewa Made Adi Baskara Joni a1, I Kadek Budi Sandika a2 \\ Program Studi Teknik Informatika, STMIK STIKOM Indonesia \\ 1dewadi.414@gmail.com, 2ikbsandika@gmail.com
}

\begin{abstract}
Abstrak
Dosen pada suatu perguruan tinggi maka memiliki kewajiban untuk melakukan tri dharma perguruan tinggi. Salah satu dari tri dharma tersebut adalah penelitian. Kegiatan penelitian dosen adalah suatu hal yang sangat penting untuk dapat dikelola dengan baik. Pengelolaan yang baik dapat meningkatkan kualitas karir dosen yang bersangkutan yang akan berdampak pada kualitas STMIK STIKOM Indonesia (STIKI) sebagai institusi pendidikan. Penelitian ini telah melalui berbagai tahapan, mulai dari analisa proses bisnis, perancangan sampai pada implementasi sistem. Berdasarkan analisa proses bisnis pada sistem yang sedang berjalan ditemukan berbagai permasalahan yang terjadi. Permasalahan utama adalah proses rekapitulasi penelitian. Sistem manual yang dijalankan memungkinkan terjadi human error dan mengakibatkan informasi yang dihasilkan tidak akurat dan tidak real time. Sistem dirancang menggunakan model perancangan terstruktur dimulai dari document flow diagram, system flow diagram, data flow diagram sampai dengan entity relationship diagram. Sistem yang dibangun telah memiliki fitur-fitur mulai dari manajemen data master, manajemen usulan penelitian sampai pada manajemen laporan penelitian. Semua proses manajemen tersebut telah dirancang untuk berjalan secara sistematis sehingga tingkat kesalahan yang disebabkan human error menjadi berkurang.
\end{abstract}

Kata kunci: Sistem, Informasi, Manajemen, Perancangan, Terstruktur.

\begin{abstract}
A lecturer at a university has the obligation to perform tri dharma college. One of the tri dharma is research. Research activities is a very important thing to be managed properly. Good management can improve the quality of the lecturer career that will have an impact on the quality of STMIK STIKOM Indonesia (STIKI) as an educational institution. This research has been through various stages, ranging from business process analysis, design until the implementation of the system. Based on the analysis of business processes in the current system found various problems. The main problem is on the process of research recapitulation. The running of manual system could be caused human error and generated inaccurate information and not real time. The system is designed using a structured design models starting from document flow diagrams, system flow diagrams, data flow diagrams until the entity relationship diagram. The bulit system has ranging features from master data management, management of research proposals until the management of the research report. All of these management processes have been designed to run systematically that could be minimized the error rate due to human error.
\end{abstract}

Keywords: System, Information, Management, Design, Structured.

\section{Pendahuluan}

STMIK STIKOM Indonesia (STIKI) adalah salah satu perguruan tinggi swasta yang ada di Bali. STIKI telah berdiri sejak tahun 2008. Dalam perkembangannya, sampai saat ini terdapat dua (2) Program Studi (Prodi) yaitu Prodi Teknik Informatika dan Sistem Komputer. Pada kedua Prodi tersebut terdapat lima puluh delapan (58) dosen yang tercatat sebagai dosen tetap. Sebagai dosen pada suatu perguruan tinggi maka memiliki kewajiban untuk melakukan tri dharma perguruan tinggi. Salah satu dari tri dharma tersebut adalah penelitian. Dosen akan melakukan kegiatan penelitian setiap semester untuk memenuhi kewajibannya yang dapat diukur kedalam 
suatu angka kredit. Angka kredit tersebut dapat diakumulasikan dengan angka kredit pada kegiatan pendidikan, pengabdian masyarakat dan penunjang untuk dapat dihitung kedalam suatu usulan jabatan fungsional akademik dosen. Hal tersebut menyebabkan kegiatan penelitian dosen adalah suatu hal yang sangat penting untuk dapat dikelola dengan baik. Pengelolaan yang baik dapat meningkatkan kualitas karir dosen yang bersangkutan yang akan berdampak pada kualitas STIKI sebagai institusi pendidikan.

Dalam melakukan kegiatan penelitian dosen, pengelolaannya dilakukan oleh Lembaga Penelitian dan Pengabdian Masyarakat (LPPM) STIKI. Saat ini penelitian yang dikelola dananya bersumber dari internal institusi dan eksternal (Kementrian Riset Teknologi dan Pendidikan Tinggi). Untuk penelitian yang dananya bersumber dari Kementrian Riset Teknologi dan Pendidikan Tinggi (Kemenristekdikti), dari proses proposal sampai pelaporan kegiatan penelitian dikelola dan dipantau melalui suatu sistem terkomputerisasi. Sistem tersebut adalah sitem berbasis web yang disebut Sistem Informasi Manajemen Penelitian dan Pengabdian Masyarakat (SIMLITABMAS). Dengan menggunakan sistem tersebut para peneliti, operator perguruan tinggi maupun pihak Kemenristekdikti dapat berkolaborasi dalam suatu sistem untuk mengelola kegiatan penelitian yang efektif dan efisien. Untuk penelitian yang dananya bersumber dari internal institusi disebut dengan program hibah Penelitian Pengembangan Dosen STIKI (PPDS). Program hibah PPDS dari proses pengumpulan proposal sampai pelaporan kegiatan penelitian dilakukan secara manual. Kendala yang dihadapi cukup beragam, mulai dari kendala keakuratan data sampai pada penyimpanan data kegiatan penelitian yang kurang baik. Permasalahan mulai muncul ketika dibutuhkan informasi mengenai status penelitian setiap dosen maupun keseluruhannya. LPPM sebagai pengelola harus mengolah data manual yang ada dan membutuhkan waktu pemrosesan yang cukup lama. Ketika informasi tersebut dibutuhkan untuk pengambilan keputusan strategis, keakuratan dan ketersediaan informasi adalah menjadi masalah yang kritis.

Agar data dapat dikelola secara terpusat dan terstruktur maka dibutuhkan suatu sistem. Sistem terkomputerisasi dan berbasis web adalah menjadi suatu solusi dari permasalahan tersebut. Berdasarkan permasalahan yang telah disampaikan, untuk dapat menyelesaikan permasalahan yang ada pada LPPM STIKI maka dilakukan penelitian. Penelitian ini akan menghasilkan suatu Sistem Informasi Manajemen yang dapat digunakan untuk mengelola penelitian dosen STIKI.

\section{Metodologi Penelitian}

Penelitian dilakukan dengan menganalisis, merancang dan membangun sistem informasi manajemen penelitian dosen pada STMIK STIKOM Indonesia. Penelitian ini terbagi atas beberapa langkah yang dapat dilihat pada gambar 1 berikut ini:

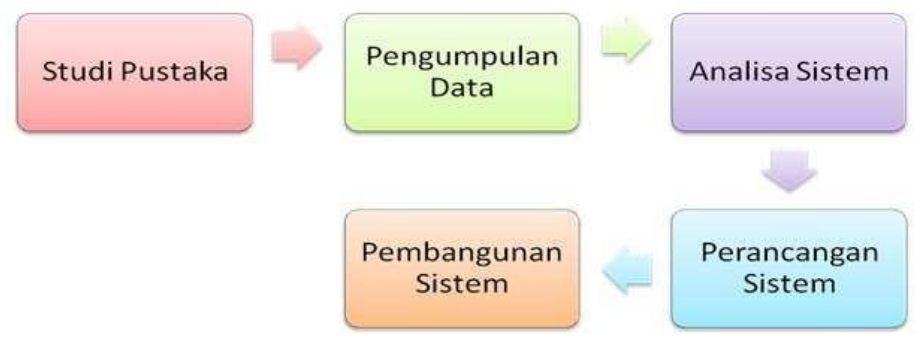

Gambar 1. Metode Penelitian

\subsection{Studi Pustaka}

Dalam penelitian ini digunakan beberapa referensi pendukung sebagai acuan dalam melakukan penelitian. Referensi tersebut berupa buku teks maupun jurnal dan prosiding. Buku teks digunakan sebagai dasar-dasar teori yang menjadi dasar dalam merancang dan membangun sistem yang dihasilkan dalam penelitian ini. Referensi jurnal dan prosiding dipergunakan untuk mempelajari penelitian-penelitian terkait dan terkini. Studi kepustakaan difokuskan pada referensi yang terkait dengan topik sistem informasi manajemen. 


\subsection{Pengumpulan Data}

Pada tahap pengumpulan data, jenis dan sumber data yang dipergunakan adalah sebagai berikut:

a. Data Primer adalah data yang diperoleh langsung dari Lembaga Penelitian dan Pengabdian Masyarakat (LPPM) STMIK STIKOM Indonesia berupa data penelitian dosen.

b. Data Sekunder adalah data yang diperoleh dari studi kepustakaan seperti data hasil penelitian terdahulu dan data lain yang didapat dari buku, jurnal ilmiah, prosiding seminar dan lain sebagainya.

Teknik pengumpulan data yang dipergunakan dalam penelitian ini adalah sebagai berikut:

a Wawancara: adalah teknik pengumpulan data dari hasil tanya jawab dengan penanggung jawab prosedur penelitian pada LPPM STMIK STIKOM Indonesia maupun para dosen STMIK STIKOM Indonesia. Wawancara dilakukan kepada Ida Bagus Ary Indra Iswara, M.Kom selaku bidang Penelitian LPPM STMIK STIKOM Indonesia. Hasil wawancara menyatakan bahwa terdapat dua jenis penelitian berdasarkan sumber dananya. Pengelolaan saat ini masih dilakukan dengan sistem manual yang mengakibatkan proses administrasi dan arsip masih belum berjalan dengan baik. Berdasarkan hal tersebut dikatakan bahwa dibutuhkan suatu sistem informasi manajemen yang dapat membantu proses pengelolaan penelitian. Wawancara dengan perwakilan dosen dilakukan kepada I Nyoman Jayanegara, M.Sn. Hasil wawancara menyatakan bahwa untuk saat ini belum ada sistem informasi yang digunakan oleh LPPM untuk mengelola seluruh kegiatan penelitian yang ada. Dikatakan juga bahwa dibutuhkan suatu sistem yang dapat mengelola data penelitian. Diharapkan dengan adanya sistem tersebut data penelitian dapat dikelola dengan lebih baik lagi dan didapatkan informasi tentang seluruh kegiatan penelitian yang pernah dilakukan dosen.

b Studi Dokumentasi: adalah teknik pengumpulan data dengan mencari data yang ada dalam dokumen terkait, buku, internet atau jurnal yang berhubungan dengan penelitian ini. Dalam hal ini didapatkan dokumen-dokumen terkait seperti Surat Keputusan Hibah Penelitian, Berita Acara, Proposal Penelitian, Laporan Penggunaan Anggaran maupun Laporan Penelitian.

\subsection{Analisa Sistem}

Analisa sistem dalam penelitian ini akan dilakukan dalam dua tahap. Tahap pertama adalah analisa sistem yang sedang berlangsung saat ini (as-is) menggunakan Document Flow Diagram. Tahap kedua adalah analisa sistem baru yang dihasilkan dari penelitian ini (to-be) menggunakan System Flow Diagram.

\subsubsection{Analisa Tahap Pertama}

Dalam analisa sistem tahap pertama akan digambarkan permasalahan yang terjadi, penyebab dan solusi yang dapat diterapkan untuk menyelesaikan permasalahan. Sistem pengelolaan penelitian dosen yang selama ini ada pada LPPM STMIK STIKOM Indonesia akan terlihat pada analisa tahap pertama ini. Terdapat beberapa proses yang dianalisa sebagai berikut:

a. Proses Pengumpulan Proposal Penelitian

Sebagai contoh yang ditunjukkan adalah pengelolaan Program Hibah Penelitian Pengembangan Dosen STIKI (PPDS). Proses dimulai dari LPPM mengumumkan jadwal kegiatan penelitian kepada seluruh calon dosen peneliti. Selanjutnya dosen peneliti akan mengumpulkan proposal kepada LPPM. Setelah dilakukan pengecekan dan administrasi oleh LPPM, terdapat dua kemungkinan keputusan yang ada. Pertama jika dinyatakan tidak sesuai akan diberikan catatan perbaikan dan mengembalikan proposal kepada dosen peneliti untuk selanjutnya diperbaiki. Kedua jika sesuai, LPPM akan merekapitulasi hasil seleksi dan mengumumkan hasil seleksi tahap awal.

b. Proses Seminar Proposal Penelitian

Proses dimulai dari LPPM menjelaskan aturan penyelenggaraan kegiatan seminar dan menyatakan kegiatan dimulai. Selanjutnya dosen peneliti akan mempresentasikan proposal penelitian yang diajukan. Berikutnya akan dilakukan penilaian oleh 
perwakilan LPPM dan pimpinan. Setelah hasil penilaian didapatkan akan dilakukan rekapitulasi penilaian oleh LPPM.

c. Proses Keputusan Pembiayaan Penelitian

Proses dimulai dengan LPPM memberikan hasil rekapitulasi penilaian seminar proposal kepada Ketua STIKOM Indonesia (STIKI). Kemudian Ketua akan mengambil keputusan. Jika diputuskan tidak dibiayai, LPPM akan menginformasikan kepada dosen peneliti yang bersangkutan. Jika diputuskan untuk dibiayai, akan ditentukan nilai pembiayaan yang akan dimuat dalam berita acara untuk selanjutnya direkapitulasi dan diterbitkan Surat Keputusan (SK) Ketua.

d. Proses Kontrak Penelitian

Proses dimulai dari LPPM menyusun surat perjanjian penugasan penelitian untuk selanjutnya ditandatangani. Setelah itu akan diberikan bersama dengan dana penelitian $70 \%$.

e. Proses Pengumpulan Laporan

Proses dimulai dari dosen peneliti mengumpulkan laporan penggunaan anggaran dan laporan akhir penelitian. Selanjutnya akan divalidasi oleh LPPM. Jika tidak sesuai, akan dikembalikan untuk diperbaiki. Jika dinyatakan sesuai, LPPM akan mengarsipkan laporan dan memberikan berita acara berikut dana penelitian $30 \%$.

\subsubsection{Analisa Tahap Kedua}

Dalam analisa tahap kedua ini akan dijelaskan kelebihan dari sistem yang baru dan akan berisi penjelasan mengenai manfaat untuk setiap fungsi yang ada. Secara umum dalam tahap analisa ini akan memberikan gambaran jelas mengenai sistem informasi manajemen yang dibangun dan diharapkan dapat menjadi solusi dari permasalahan yang terjadi pada LPPM STMIK STIKOM Indonesia.

a. Proses Pengumpulan Proposal Penelitian

Proses-proses yang ada pada sistem baru yang dirancang secara garis besar tidak banyak yang berubah. Pada alur proses bisnis yang ada tidak mengalami perubahan signifikan. Perubahan hanya pada proses yang sebelumnya dilakukan secara manual kemudian pada sistem yang dirancang dilakukan secara komputerisasi. Namun, dari hasil analisa ditetapkan masih banyak proses yang tetap dilakukan secara manual. Hal tersebut dikarenakan beberapa hal seperti misalnya prosedur yang mensyaratkan dokumen tetap harus diproses secara manual. Proses yang dikomputerisasi adalah untuk pengumpulan proposal (unggah) softcopy yang dilakukan melalui sistem. Proses validasi proposal yang diunggah dilakukan oleh LPPM melalui sistem terkomputerisasi.

b. Proses Seminar Proposal Penelitian

Secara garis besar proses-proses yang ada masih tetap dilakukan secara manual dan tidak banyak yang berubah. Perubahan terjadi hanya pada proses rekapitulasi hasil penilaian yang selama ini dilakukan manual oleh LPPM. Efisiensi penggunaan dokumen hanya pada hasil rekapitulasi penilaian seminar proposal. Untuk sistem yang dirancang hasil seminar disimpan kedalam database dan hasil rekapitulasi dapat dicetak kapanpun dibutuhkan. Pada sistem terkomputerisasi yang dirancang, proses rekapitulasi secara otomatis dilakukan sistem ketika LPPM memasukkan hasil penilaian seminar proposal ke sistem.

c. Proses Keputusan Pembiayaan Penelitian

Pada sistem yang dirancang, hasil rekapitulasi dapat dicetak melalui sistem yang datanya diambil dari database. Proses rekapitulasi berita acara penilaian yang diputuskan oleh ketua STIKI dan proses penyusunan surat keputusan hibah dirancang menjadi terkomputerisasi. Hal tersebut diharapkan memudahkan kerja dari LPPM dan mengurangi kemungkinan kesalahan (human error).

d. Proses Kontrak Penelitian

Proses yang dikomputerisasi hanya pada proses penyusunan surat perjanjian penugasan penelitian. LPPM langsung dapat mencetak surat perjanjian tersebut yang akan diproses oleh sistem dengan mengambil data pada database. Dengan proses komputerisasi tersebut diharapkan mengurangi kemungkinan kesalahan (human error).

e. Proses Pengumpulan Laporan 
Pada sistem yang dirancang, terdapat perubahan alur proses. Pada sistem manual yang ada sebelumnya, ketika laporan telah divalidasi dan dinyatakan sesuai akan langsung dibuatkan berita acara penerimaan dana 30\% oleh LPPM. Perubahan alur terjadi ketika laporan telah diarsipkan, LPPM akan meminta peneliti untuk mengunggah laporan penelitian. Selanjutnya akan divalidasi oleh LPPM dan jika dinyatakan sesuai, berita acara penerimaan dana $30 \%$ akan diproses.

\subsection{Perancangan Sistem}

Proses-proses yang terkomputerisasi dan aliran data dari sistem yang dibangun akan di gambarkan menggunakan data flow diagram. Untuk rancangan database yang akan digunakan pada aplikasi digambarkan menggunakan entity relationship diagram.

\subsubsection{Data Flow Diagram - Level Konteks}

DFD level konteks menggambarkan sistem secara kontekstual. Pada level ini hanya terdapat satu proses dan external entities yang berinteraksi dengan sistem. Untuk lebih jelasnya, berikut dibawah ini pada Gambar 2 adalah data flow diagram level konteks.

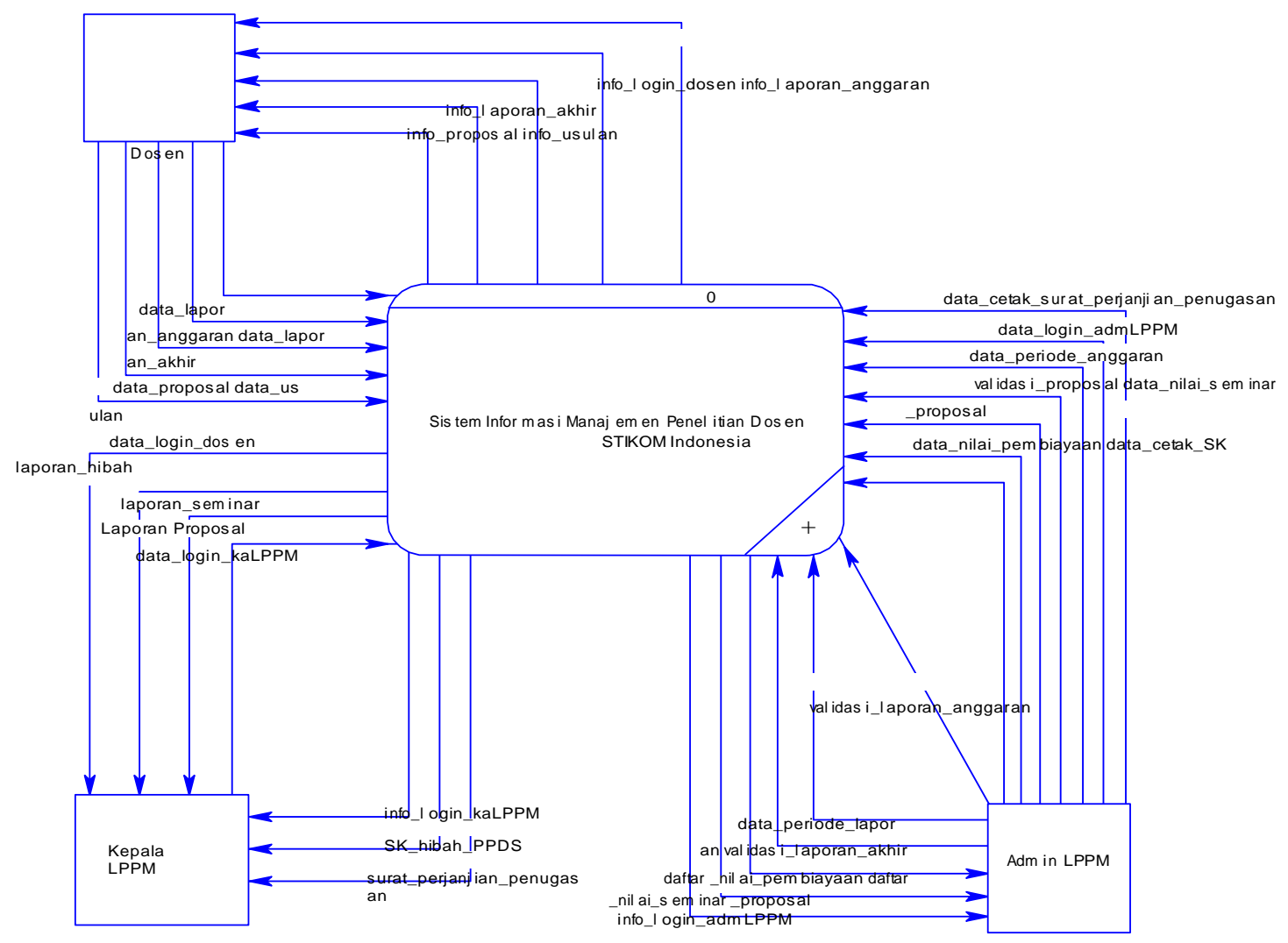

Gambar 2. Data Flow Diagram - Level Konteks

Pada Gambar 2 diatas dapat dilihat terdapat tiga external entity. External entity Dosen berinteraksi dengan sistem untuk mengelola data berupa data login, data usulan, data proposal maupun data laporan. External entity Admin LPPM berinteraksi dengan sistem untuk mengelola data berupa data login, data periode anggaran, data periode laporan, validasi proposal, validasi laporan, data cetak SK, data nilai seminar proposal, data nilai pembiayaan maupun data surat perjanjian penugasan. External entity Kepala LPPM berinteraksi dengan sistem untuk mengelola data berupa data login maupun laporan-laporan yang dapat dihasilkan sistem. 


\subsubsection{Entity Relationship Diagram}

Entity Relationship Diagram (ERD), merupakan hasil dari rancangan data store yang terdapat pada Data Flow Diagram (DFD). Dalam karya ilmiah ini akan disajikan ERD pada level Conceptual Data Model (CDM). Berikut dibawah ini adalah ERD-CDM dari Sistem Informasi Manajemen Penelitian Dosen STIKOM Indonesia

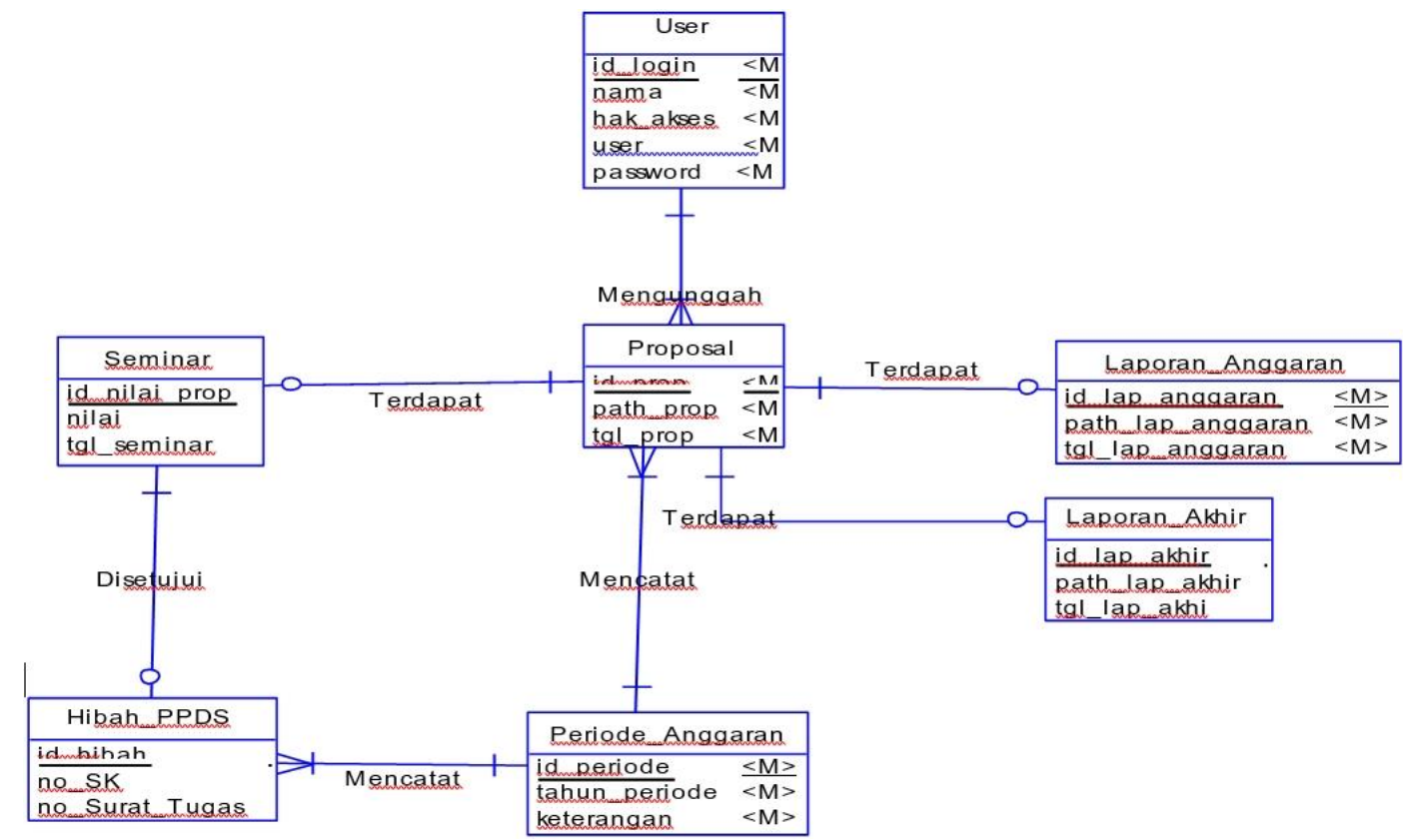

Gambar 3. Entity Relationship Diagram - Conceptual Data Model

Pada Gambar 3 diatas dapat dilihat adalah ERD-CDM dari Sistem Informasi Manajemen Penelitian Dosen STIKOM Indonesia. Terdapat 7 tabel pada diagram ini yang saling berelasi. Relasi yang terbentuk ada dua yaitu one-to-one dan one-to-many.

\section{Kajian Pustaka}

\subsection{Pengertian Sistem}

Dalam Fatta, menurut Murdick dan Ross mendefinisikan sistem sebagai seperangkat elemen yang digabungkan satu dengan lainnya untuk suatu tujuan bersama. Menurut Fatta, sistem adalah elemen-elemen yang saling berhubungan dan membentuk satu kesatuan atau organisasi [1]. Menurut Kusrini, sistem merupakan kumpulan elemen yang saling berkaitan yang bertanggung jawab memproses masukan (input) sehingga menghasilkan keluaran (output). Dalam Kusrini, menurut Mc. Leod mendefinisikan Sistem sebagai sekelompok elemen-elemen yang teritegrasi dengan maksud yang sama untuk mencapai suatu tujuan [2]. Menurut FitzGerald dkk dalam Jogiyanto, sistem adalah suatu jaringan kerja dari prosedur-prosedur yang saling berhubungan, berkumpul bersama-sama untuk melakukan suatu kegiatan atau untuk menyelesaikan suatu sasaran tertentu [3]. Pengertian sistem telah dikenal dan didefinisikan oleh banyak ahli. Mengacu pada beberapa definisi sistem di atas, maka dapat disimpulkan bahwa sistem merupakan kumpulan elemen-elemen yang saling terkait dan membentuk kesatuan yang bertanggung jawab memproses masukan (input) sehingga menghasilkan keluaran (output) yang memiliki maksud yang sama untuk mencapai suatu tujuan.

\subsection{Konsep Dasar Sistem Informasi}

Menurut Kristanto [4] suatu sistem mempunyai tujuan atau sasaran. Tujuan biasanya dihubungkan dengan ruang lingkup yang lebih luas dan sasaran dalam ruang lingkup yang lebih sempit. Sasaran dari sistem sangat menentukan masukan yang dibutuhkan sistem dan keluaran yang dihasilkan oleh sistem. Sistem dapat dikatakan berhasil apabila dapat mencapai 
tujuan atau sasaran. Suatu informasi dikatakan bernilai apabila memiliki manfaat yang lebih efektif dan efisien jika dibandingkan dengan biaya untuk mendapatkannya. Informasi dapat dihasilkan dari sistem informasi yang disebut juga pocessing system atau information processing system atau juga information generation system. Sistem informasi adalah "Suatu kombinasi dari orang-orang, fasilitas, teknologi, media, prosedur-prosedur dan pengendalian yang ditujukan untuk mendapatkan jalur komunikasi penting, memproses tipe rutin tertentu, memberi sinyal kepada manajemen dan lainnya terhadap kejadian-kejadian internal dan eksternal yang penting menyediakan suatu dasar untuk pengambilan keputusan yang cerdik" [4]. Menurut Sutabri [5] sistem informasi adalah suatu sistem di dalam suatu organisasi yang mempertemukan kebutuhan pengolahan transaksi harian yang mendukung fungsi operasi organisasi yang bersifat manajerial dengan kegiatan strategi dari suatu organisasi. Sistem informasi diharapkan dapat menyediakan kepada pihak luar tertentu dengan laporan yang diperlukan.

\subsection{Sistem Informasi Manajemen}

Menurut O'Brien, sistem informasi manajemen memberikan informasi dalam bentuk laporan dan tampilan kepada manajer dan banyak pelaku bisnis [6]. Menurut Jogiyanto, sistem informasi manajemen merupakan suatu penerapan sistem informasi di dalam organisasi untuk mendukung informasi-informasi yang dibutuhkan oleh semua tingkatan manajemen [3]. Sistem informasi manajemen tergantung dari besar kecilnya organisasi dan dapat terdiri dari sistemsistem informasi sebagai berikut: 1.Sistem informasi akuntansi (accounting information system); 2.Sistem informasi pemasaran (marketing information system); 3.Sistem informasi manajemen persediaan (inventory management information system); 4.Sistem informasi personalia (personel information system); 5.Sistem informasi distribusi (distribution information system);6.Sistem informasi pembelian (purchasing information system); 7.Sistem informasi kekayaan (treasury information system); 8.Sistem informasi analis kredit (credit analysis information system); 8.Sistem informasi penelitian dan pengembangan (research and development information system)

\section{Hasil dan Pembahasan}

\subsection{Menu Master}

Terdapat empat sub-menu pada menu master ini. Sub-menu tersebut diantaranya Master Dosen, Master Admin, Master Rumpun IImu dan Master Jenis Nilai. Pada dasarnya struktur pada empat sub-menu itu adalah sama, yang membedakan adalah data yang dimanipulasi. Sebagai contoh akan ditampilkan sub-menu master dosen. Untuk menampilkan data dosen yang sudah tersimpan pada database dapat diakses menu data dosen. Pada menu tersebut terdapat pilihan untuk manipulasi data yaitu dapat menambah, mengubah dan menghapus data. Untuk lebih jelasnya dapat dilihat pada Gambar 4 berikut.

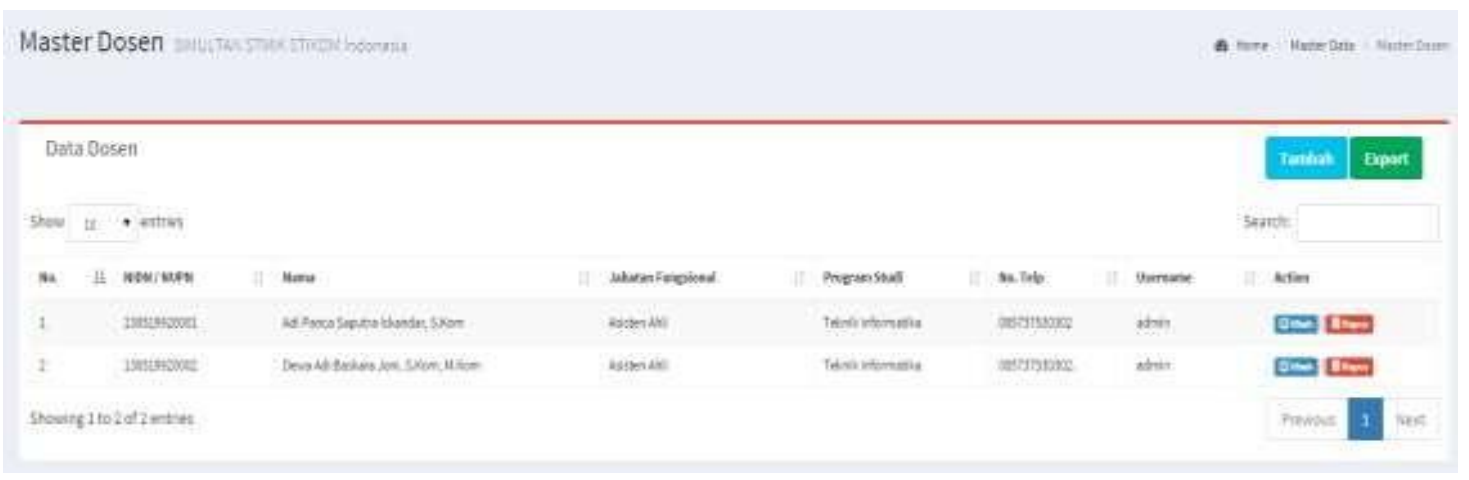

Gambar 4. Menu Data Dosen

Jika ingin menghapus data, cukup memilih data yang ingin dihapus kemudian menekan tombol hapus. Proses hapus ini tidak akan menghilangkan data dosen yang bersangkutan dari database, namun proses yang dilakukan adalah meng-update status dosen yang bersangkutan menjadi non-aktif. Hal tersebut akan mengakibatkan dosen yang bersangkutan tidak akan 
ditampilkan lagi pada menu data dosen. Jika ingin mengubah data dosen, dapat dilakukan dengan memilih data yang akan diubah kemudian menekan tombol ubah. Hal tersebut akan menampilkan form yang berisi data dosen yang ingin dirubah seperti pada Gambar 5 . Selanjutnya dapat dirubah dan disimpan kembali perubahan yang dilakukan. Jika ingin menambah data dosen, dapat menekan tombol tambah dan akan ditampilkan form seperti pada gambar 5 namun dalam keadaan kosong. Untuk lebih jelasnya dapat dilihat pada Gambar 5 berikut.

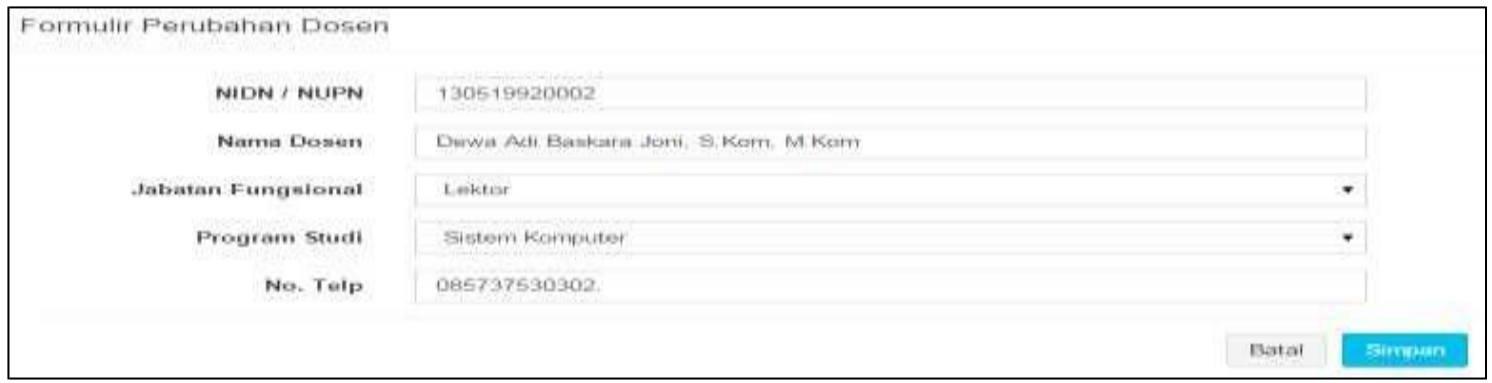

Gambar 5. Menu Ubah Data Dosen

\subsection{Usulan}

Pada sistem informasi manajemen ini para peneliti (dosen) dapat mengajukan usulan penelitan melalui 5 tahap pengisian data usulan. Untuk lebih jelasnya dapat dilihat pada Gambar 6 sampai 10 berikut.

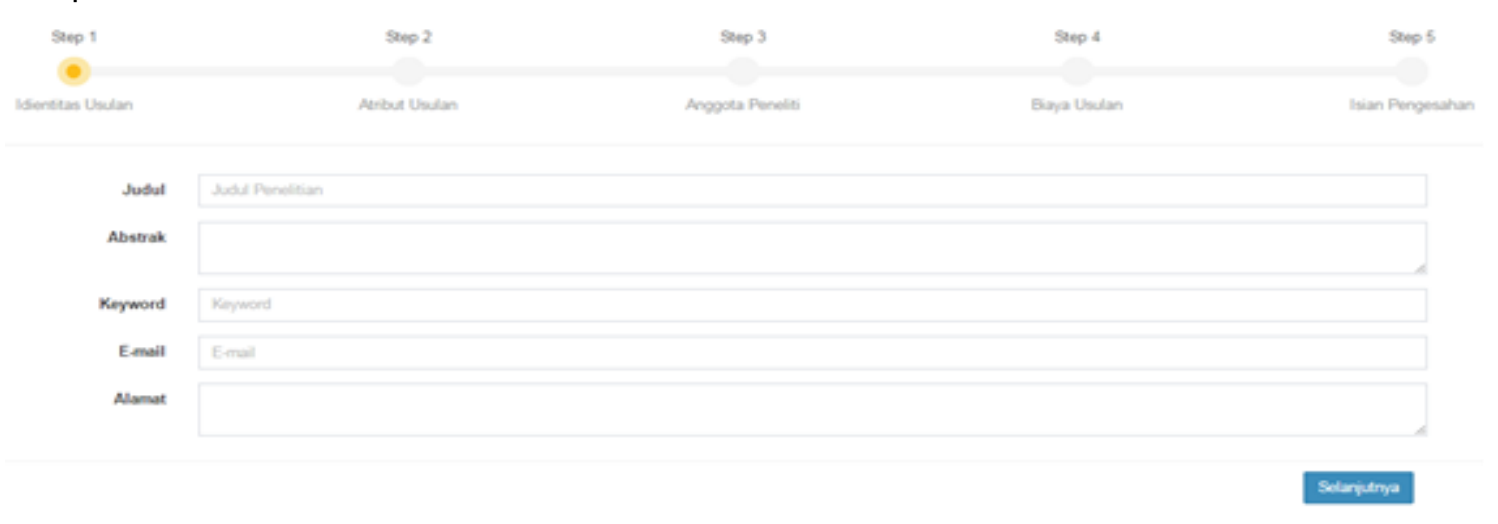

Gambar 6. Usulan Tahap 1

Pada Gambar 6 diatas adalah tahap pertama, pengusul akan mengisikan data berupa judul, abstrak, keyword, e-mail dan alamat. Jika sudah selesai maka dapat menekan tombol selanjutnya untuk dapat masuk pada tahap 2 yang dapat dilihat pada gambar 7 berikut.

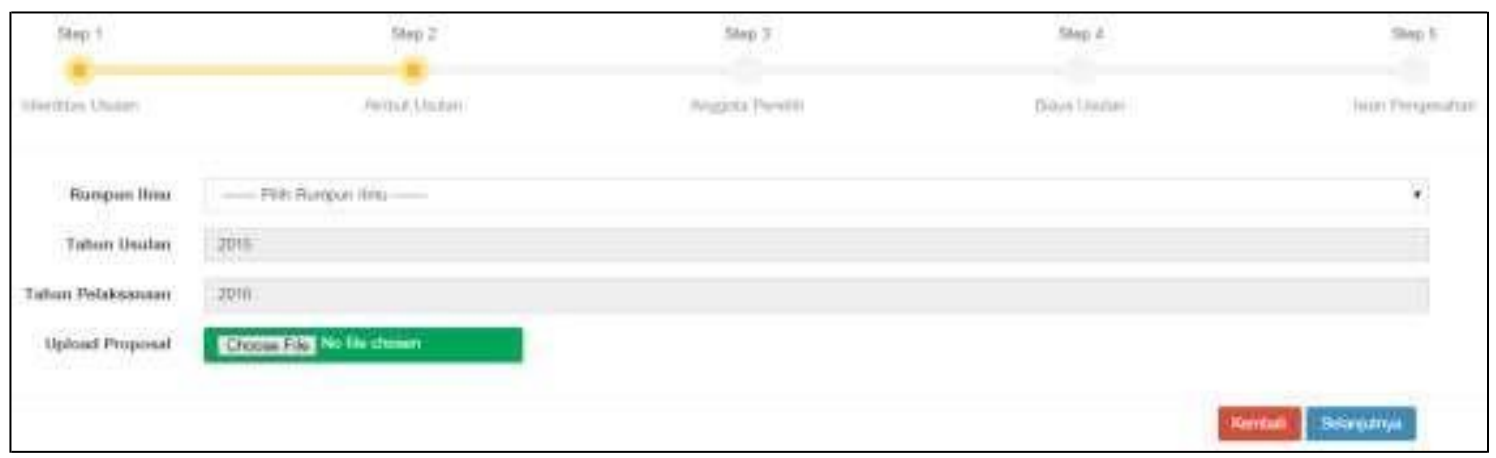

Gambar 7. Usulan Tahap 2 
Pada Gambar 7 diatas pengusul akan memilih rumpun ilmu yang sesuai dengan bidang penelitiannya dan memilih file proposal yang akan diunggah. Utnuk tahun usulan dan tahun pelaksanaan akan terisi otomatis sesuai dengan periode usulan yang dibuka.

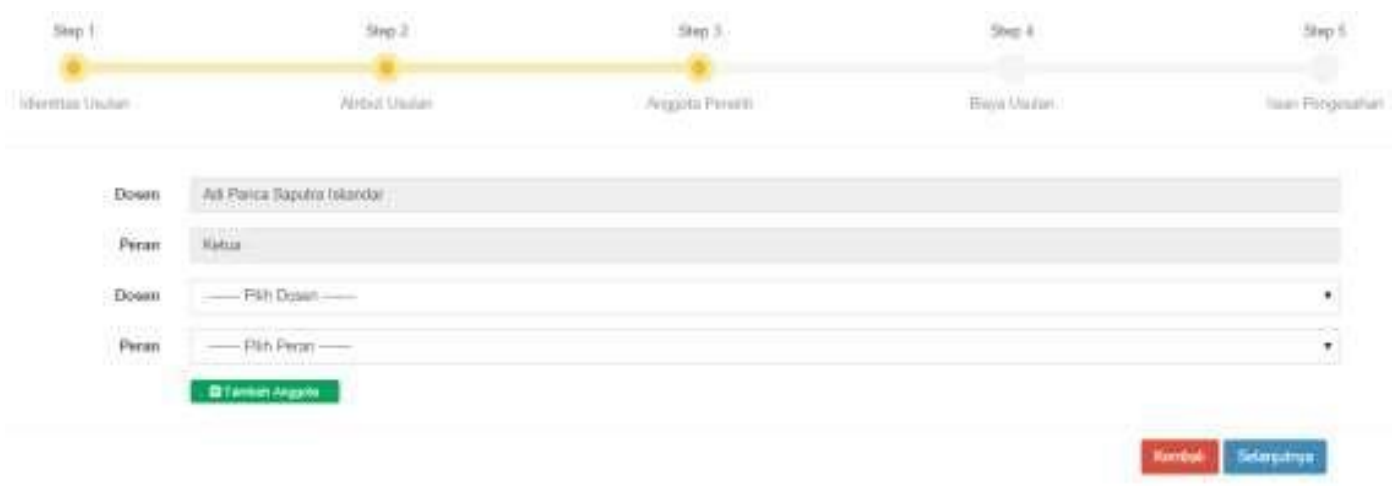

\section{Gambar 8. Usulan Tahap 3}

Pada Gambar 8 diatas, pengusul akan mengisi anggota penelitinya. Untuk jumlah anggota peneliti disesuaikan dengan program penelitian atau hibah yang diikuti oleh yang bersangkutan. Pengusul dapat langsung memilih data dosen yang akan menjadi anggota peneliti dan perannya. Data dosen yang dapat dipilih adalah yang ada pada master data dosen.

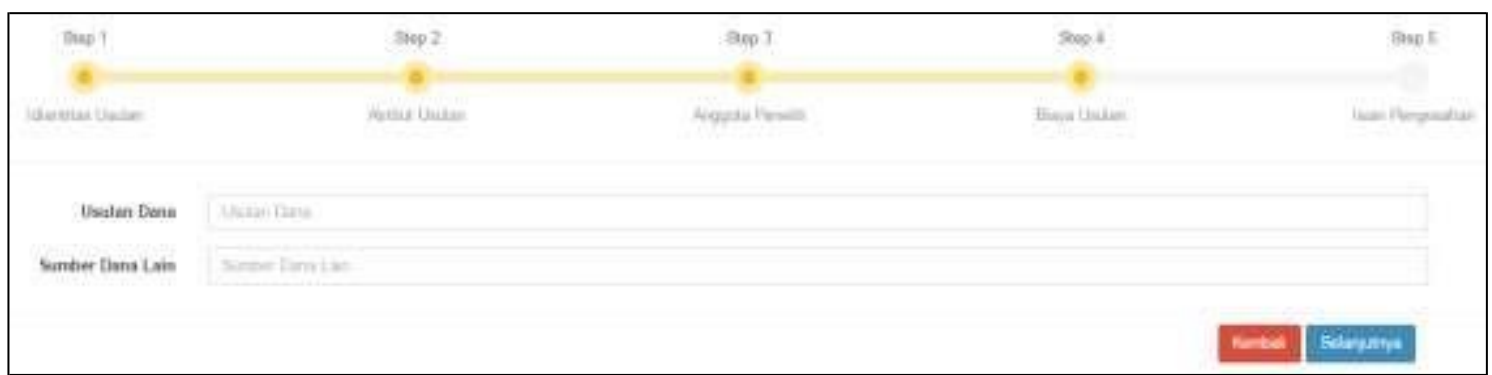

\section{Gambar 9. Usulan Tahap 4}

Pada Gambar 9 diatas, pengusul akan memasukkan usulan dana penelitian yang diajukan. Jika dalam penelitiannya juga terdapat sumber dana lain, dapat dimasukkan pada textbox yang ada.

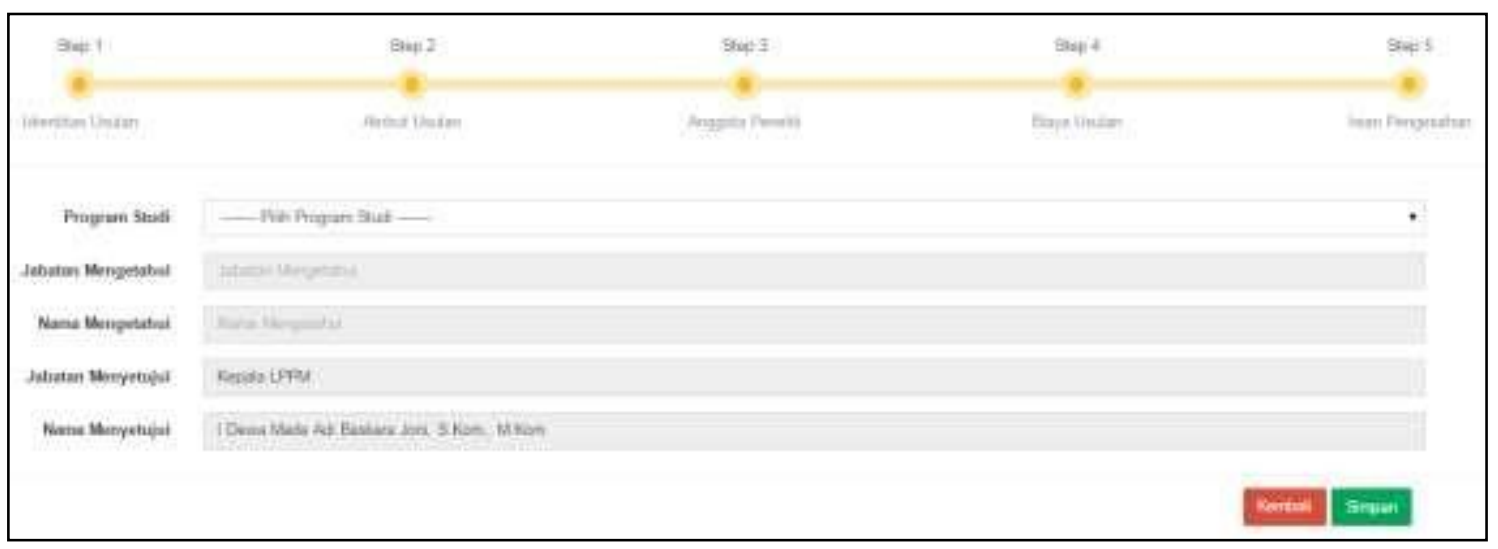

Gambar 10. Usulan Tahap 5 
Pada Gambar 10 diatas adalah tahap akhir dari pengajuan usulan. Pada tahap ke-5 ini, pengusul hanya perlu memilih program studi yang bersangkutan. Secara otomatis data terkait dengan lembar halaman pengesahan akan terisi.

\subsection{Monitoring}

Pada sistem ini setiap usulan yang diajukan akan dimonitoring oleh admin LPPM. Proses monitoring akan mengecek berkas yang diunggah ke dalam sistem. Monitoring dilakukan mulai dari berkas usulan proposal, laporan penelitian, laporan penggunaan anggaran sampai pada publikasi yang dilakukan. Untuk lebih jelasnya dapat dilihat pada Gambar 11 berikut.

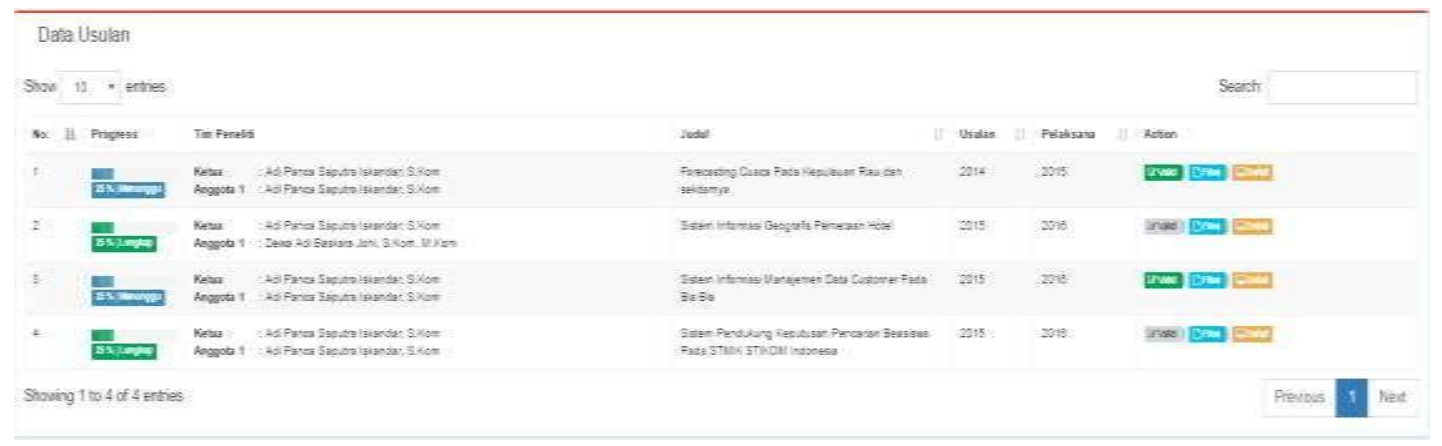

Gambar 11. Monitoring Usulan

Pada gambar diatas dapat dilihat kolom "Progress" yang menandakan status dari berkas yang diunggah. Admin dapat melihat data tim peneliti, judul, tahun usulan serta tahun pelaksanaan. Aksi yang dapat dilakukan admin adalah mengecek berkas yang diunggah, mengecek detil usulan dan melakukan validasi jika berkas yang diunggah sudah dianggap valid.

\section{Kesimpulan}

Berdasarkan hasil penelitian yang telah dilakukan melalui perancangan, implementasi dan analisis dapat disimpulkan beberapa hal sebagai berikut: ditemukan bahwa proses bisnis pengelolaan penelitian secara manual mengakibatkan berbagai permasalahan. Permasalahan utama adalah pada rekapitulasi penelitian yang mengakibatkan informasi yang dihasilkan tidak akurat dan real time. Sistem yang dibangun telah memiliki fitur-fitur mulai dari manajemen data master, manajemen usulan penelitian sampai pada manajemen laporan penelitian. Semua proses manajemen tersebut telah dirancang untuk berjalan secara sistematis sehingga tingkat kesalahan yang disebabkan human error menjadi kecil. Saran yang dapat diberikan untuk pengembangan penelitian ini selanjutnya adalah sebagai berikut: Sistem dapat ditambahkan fitur-fitur seperti chating maupun mail untuk memudahkan komunikasi antara peneliti maupun admin. Pada sistem terdapat halaman dashboard yang dapat melihat kinerja penelitian dosen pada STMIK STIKOM Indonesia.

\section{Daftar Pustaka}

[1] A. H. Fatta, Analisis dan Perancangan Sistem Informasi Untuk Keunggulan Bersaing perusahaan dan Organisasi Moderen. Yogyakarta: Andi, 2007.

[2] Kusrini, Konsep dan Aplikasi Sistem Pendukung Keputusan. Yogyakarta: Andi, 2007.

[3] H. M. Jogiyanto, Analisis dan Desain Sistem Informasi: Pendekatan Terstruktur Teori dan Praktek Aplikasi Bisnis. Yogyakarta: Andi, 2006.

[4] A. Kristanto, Perancangan Sistem Informasi dan Aplikasinya. Yogyakarta: Gaya Media, 2008.

[5] T. Sutabri, Analisa Sistem Informasi. Yogyakarta: Andi, 2004.

[6] J. A. O'Brien and G. M. Marakas, Management Information System, 9th ed. Jakarta: Salemba Empat dan McGraw-Hill Education, 2014. 